\title{
Taxonomic Differentiation of Bacteriophages of Lactococcus lactis by Electron Microscopy, DNA-DNA Hybridization, and Protein Profiles
}

\author{
By VOLKMAR BRAUN, JR, STEFAN HERTWIG, HORST NEVE, \\ ARNOLD GEIS AND MICHAEL TEUBER* \\ Institut für Mikrobiologie, Bundesanstalt für Milchforschung, D-2300 Kiel 1, \\ Federal Republic of Germany
}

(Received 16 January 1989; revised 8 May 1989; accepted 24 May 1989)

\begin{abstract}
Thirty-seven virulent and 19 temperate bacteriophages of Lactococcus lactis subsp. lactis and Lactococcus lactis subsp. cremoris were classified in a taxonomic system on the basis of morphology, DNA-DNA hybridization, and protein composition. As judged from electron microscopy and susceptibility to cleavage by restriction endonucleases, the genome of all the bacteriophages investigated is composed of double stranded DNA. Seven virulent phage groups were recognized: types P034 (genome size 18.1 kilobase pairs, kb), P001 (20.2 kb), P008 (29.7 kb), P335 (36.4 kb), P026 (51.5 kb), P107 (51.5 kb), and P087 (54.5 kb). In addition, two temperate phage groups were established: types TP-40-3 (genome size $42 \cdot 1 \mathrm{~kb}$ ) and TP-936-1 $(37.8 \mathrm{~kb})$. Phages within each group revealed strong DNA homology and similar protein compositions, whereas no significant DNA homology and different proteins were found in phages of different groups. Virulent phages of group P335 exhibited strong DNA homology with the temperate phages of group TP-936-1.
\end{abstract}

\section{INTRODUCTION}

Bacteriophages of mesophilic starter cultures used by the dairy industry for the production of cheese, sour milk, and cream were recognized as early as 1935 (Whitehead \& Cox, 1935). Due to the great economic impact of faulty dairy fermentations, a large body of information on the occurrence and properties of bacteriophages specific for Lactococcus lactis and its subspecies lactis and cremoris has since been collected (Coveney et al., 1987; Jarvis, 1984a; Lautier \& Novel, 1987; Powell \& Davidson, 1985; Relano et al., 1987; Teuber \& Lembke, 1983; Teuber \& Loof, 1987). An exciting novel development is the discovery of bacteriophage insensitivity mechanisms coded on plasmids (Klaenhammer, 1987). Such 'phage resistance' plasmids may be transferred by conjugation to other strains (Baumgartner et al., 1986; De Vos et al., 1984; McKay \& Baldwin, 1984; Neve et al., 1987; Sanders \& Klaenhammer, 1983; Wetzel et al., 1986). In addition, genetic information determining bacteriophage insensitivity phenomena has been cloned and subsequently transferred by transformation (Laible et al., 1987; Simon et al., 1985). However, very little is known of the biochemical basis of bacteriophage resistance in Lactococcus. Development of bacteriophage resistant starter cultures requires knowledge of as many as possible of the bacteriophages likely to exist in a dairy environment in order to make predictions of the usefulness and stability of genetically constructed resistant starter strains.

Using bacteriophages of lactococci collected from the industry over more than two decades, we have compared the previously morphologically defined bacteriophage types (Lembke et al., 1980; Teuber \& Lembke, 1983) by exhaustive electron microscopic characterization, by DNA-DNA hybridization, and by electrophoresis of bacteriophage proteins. Evidence is presented for the existence of at least seven genetically distinct virulent phage types and two temperate phage types, one of these being clearly related to a virulent type. The main three phage types (P001, P008, P335) collected in Germany are similar to those already described in the literature (Coveney et al., 1987; Jarvis, 1984a) and occur throughout the world. 


\section{METHODS}

Bacteriophages and host bacteria. Virulent phages and their bacterial host strains are listed in Table 1. Table 2 summarizes the temperate bacteriophages and their lysogenic host strains. The previously described virulent prolate-headed phage c6A (Powell \& Davidson, 1985) and the temperate phage BK5-T (Jarvis, 1984b) were included in this study.

The bacterial strains were propagated at $30^{\circ} \mathrm{C}$ in M17-broth (Terzaghi \& Sandine, 1975). The medium was supplemented with $2 \mathrm{mM}^{-} \mathrm{CaCl}_{2}$ when phage lysates were prepared. The bacteria were stored at $-72^{\circ} \mathrm{C}$ in

\section{Table 1. Virulent bacteriophages used in this study}

All phages were originally isolated from dairy environments, e.g. milk, sour milk, cheese, whey or starter cultures. Most phages of group P008 were grown on either Lactococcus lactis subsp. lactis (L.l.s.l.) F7/2 or Bu2-60, which both show a restriction-modification-negative phenotype. Phages P221BN, P123BN and P114-4BN can only be grown on the Lactococcus lactis subsp. cremoris (L.l.s.c.) strains indicated in the Table. Phages of the type $\mathrm{P} 001$ were, for historical reasons, grown on L.l.s.l. H42. This strain is phenotypically identical to F7/2 but differs from F7/2 by the absence of a small cryptic plasmid. Phages P109 and P127 were specific for L.I.s.c. strains. Phages P142ag, P026 and P087 can only be grown on the indicated host strains.

Phage

Type phage P00

P159

P167

P330

P177

P220

P029

P109

P127

c6A

Type phage P008

P315

P232

P039

$\mathrm{P} 003$

P008S

P096

P053

P031

P179

P221BN

P123BN

P114-4BN

$\mathrm{P} 010$

P239

P228

P323

Type phage P335

P013

P002

P047

P142ag

Type phage P034

P369

Type phage P107

Type phage P026

Type phage P087
Propagating host and strain

$$
\begin{aligned}
& \text { L.l.s.l. } \\
& \text { L.l.s.l. } \\
& \text { L.l.s.l. } \\
& \text { L.l.s.l. } \\
& \text { L.l.s.l. } \\
& \text { L.l.s.l. } \\
& \text { L.l.s.l. } \\
& \text { L.l.s.c. } \\
& \text { L.l.s.c. } \\
& \text { S.l. } \dagger
\end{aligned}
$$

L.l.s.l.

L.l.s.l.

L.l.s.l.

L.l.s.l.

L.l.s.l.

L.l.s.l.

L.l.s.l.

L.l.s.l.

L.l.s.l.

L.l.s.l.

L.l.s.c.

L.l.s.c.

L.l.s.c.

L.l.s.l.

L.l.s.l.

L.l.s.l.

L.l.s.l.

L.l.s.l.

L.l.s.l.

L.l.s.l.

L.l.s.c.

L.l.s.c.

L.l.s.l.

L.l.s.l.

L.l.s.l.

L.I.s.l.

L.l.s.l.

H42
H42
H42
H42
H42
H42
H42
Wg2*
Wg2
c6

F7/2

F $7 / 2$

F7/2

F7/2

F7/2

F $7 / 2$

F7/2

F7/2

F7/2

F7/2

P8/11-32

P8/12-58

P8/12-55

Bu2-60

Bu2-60

Bu2-60

Bu2-60

F7/2

F7/2

F7/2

$\mathrm{Wg} 2$

S22n-1

F7/2

F7/2

F7/2

Bst5

C13
Year of isolation

Source

1971

1979

1979

1979

1979

1978

1977

1978

1978

1971

1979

1979

1978

1977

1982

1978

1978

1978

1979

1982

1982

1982

1971

1979

1979

1979

1979

1971

1977

1978

1978

1978

1978

1978

1977

1978
Germany

Germany

Thailand

Germany

Germany

France

Germany

Germany

Germany

Australia

Germany

Thailand

Germany

Germany

Germany

Germany

Germany

Germany

Thailand

Germany

Germany

Germany

Thailand

Netherlands

Norway

Germany

France

Germany

Germany

Germany

Sweden

Germany

Germany

Germany

Germany

Germany

* Strain was originally obtained from NIZO, Ede, the Netherlands.

† Data and taxonomy from Powell \& Davidson (1985), Streptococcus lactis. 
Table 2. Temperate bacteriophages used in this study

The phages were released from the indicated host bacteria by UV-irradiation.

\begin{tabular}{cccc} 
Phage & \multicolumn{2}{c}{ Lysogenic host and strain } \\
Type phage TP-C10 & L.l.s.l. & C10 \\
TP-712 & L.l.s.l. & NCDO 712 \\
TP-40-3 & L.l.s.l. & $40-3$ \\
TP-21-2 & L.l.s.l. & $21-2$ \\
TP-P2/1-3 & L.l.s.c. & P2/1-3 \\
Type phage TP-936-1 & L.l.s.c. & $936-1$ \\
TP-951-1 & L.l.s.c. & $951-1$ \\
TP-901-1 & L.l.s.c. & $901-1$ \\
TP-938-2 & L.l.s.c. & $938-2$ \\
TP-918 & L.l.s.c. & 918 \\
TP-Bu2-K5 & L.l.s.l. & Bu2-K5 \\
TP-3106 & L.l.s.l. & 3106 \\
TP-3107 & L.l.s.c. & 3107 \\
TP-Wis98.1 & L.l.s.l. & Wis98.1 \\
TP-Bus3018 & L.l.s.c. & Bus3018 \\
TP-Bus3021 & L.l.s.c. & Bus3021 \\
TP-11-13 & L.l.s.c. & $11-13$ \\
TP-Wis3-1 & L.l.s.c. & Wis3-1 \\
BK5-T* & S.c. $\dagger$ \\
* Data from Jarvis $(1984 b)$. & \\
$\dagger$ Taxonomy from Jarvis (1984b), Streptococcus cremoris.
\end{tabular}

reconstituted skimmed milk. For the induction of the temperate phages exponential-phase cultures were irradiated with UV-light $(260 \mathrm{~nm})$.

Phage purification and isolation of phage DNA. Concentration and purification of the phages were essentially done according to Yamamoto et al. (1970). The phages were concentrated by a two-step precipitation with $5 \%$ $(\mathrm{w} / \mathrm{v})$ and $10 \%(\mathrm{w} / \mathrm{v})$ polyethylene glycol 6000 in the presence of $1 \mathrm{M}-\mathrm{NaCl}$. They were purified by two caesium chloride step gradients. The procedure of Maniatis et al. (1982) was used for the extraction of the DNA.

Electron microscopy. The phages were negatively stained with $2 \%(\mathrm{w} / \mathrm{v})$ uranyl acetate and examined in a Philips EM300 at an acceleration voltage of $80 \mathrm{kV}$ (Lembke et al., 1980).

Determination of the phage genome sizes. The aqueous spreading technique described by Evenson (1977) was used; the internal standard was the circular DNA of the phage PM2 (9.7 kilobase pairs; Boehringer Mannheim). The DNAs were photographed in a Philips EM 300 at $40 \mathrm{kV}$, and the contour lengths of the molecules were measured with a Morphomat 10 picture analysis system (Zeiss).

Restriction enzyme analysis. The phage DNAs were digested with restriction endonucleases (Boehringer Mannheim) according to the supplier's recommendations. DNA fragments were separated on $0.8 \%(\mathrm{w} / \mathrm{v})$ agarose gels in TBE buffer (Maniatis et al., 1982), and the fragment sizes were determined from the co-migrating DNA fragments of a HindIII/EcoRI-digest of phage $\lambda$ DNA (Boehringer Mannheim).

DNA-DNA hybridization. DNA fragments were transferred to Zeta-Probe membranes (Bio-Rad) according to Southern (1975) and hybridized under stringent conditions $\left[50 \%(\mathrm{v} / \mathrm{v})\right.$ formamide, $\left.42^{\circ} \mathrm{C}\right]$ with chemically labelled (Chemiprobe Kit, Biozym) phage DNA. Antigenic sulphone groups were coupled to the cytosine moieties of the DNA. After hybridization, the membranes were washed for $30 \mathrm{~min}$ at $68^{\circ} \mathrm{C}$ in $2 \times \operatorname{SSC}(1 \times$ SSC is $0.15 \mathrm{M}-\mathrm{NaCl}$ plus $0.015 \mathrm{M}$-sodium citrate, $\mathrm{pH} 7.0$ ) plus $0.1 \%(\mathrm{w} / \mathrm{v}) \mathrm{SDS}$ and for $30 \mathrm{~min}$ at room temperature in $0.1 \times \mathrm{SSC}$ plus $0.1 \%(\mathrm{w} / \mathrm{v})$ SDS. The labelled DNAs were visualized by a specific monoclonal antibody reaction, and washed in $0.5 \mathrm{M}-\mathrm{NaCl}$ plus $0.5 \%(\mathrm{v} / \mathrm{v})$ Brij $35 \mathrm{~T}$ for three $\times 10 \mathrm{~min}$ at room temperature. An alkaline phosphatase antiimmunoglobulin antibody conjugate was added, and the membrane was washed in $0.5 \mathrm{M}-\mathrm{NaCl}$ plus $0.3 \%(\mathrm{v} / \mathrm{v}) \mathrm{Brij}$ $35 \mathrm{~T}$ for three $\times 20 \mathrm{~min}$ at room temperature followed by the addition of a chromogenic substrate.

SDS-polyacrylamide gel electrophoresis. Purified phage particles were dialysed against double distilled water, and were suspended in an equal volume of sample buffer $[0.12 \mathrm{M}-\mathrm{Tris} / \mathrm{HCl}(\mathrm{pH} 6.75), 20 \%(\mathrm{v} / \mathrm{v})$ glycerol, $4 \%(\mathrm{w} / \mathrm{v})$ SDS, $10 \%(\mathrm{v} / \mathrm{v}) \beta$-mercaptoethanol]. The phage particles were disintegrated by boiling at $100^{\circ} \mathrm{C}$ for $10 \mathrm{~min}$ and electrophoresed on a $12.0 \%(\mathrm{w} / \mathrm{v})$ polyacrylamide gel at $30 \mathrm{~mA}$ as described by Laemmli (1970). The molecular mass marker mixture SDS-7 (Sigma) was used for calibration. 


\section{RESULTS}

\section{Electron microscopy}

The virulent phages listed in Table 1 belong to seven different morphological groups. Five of these groups, represented by the type phages P008, P335, P026, P107 and P087, consist of phages with isometric heads, differing in head size, and in tail length and structure. The two prolate-headed phage groups with the type phages P001 and P034 differed in tail structure. The great majority of the virulent phages examined belonged to the phage groups P001, P008 and P335, and only two to group P034 (P034 and P369). Phages P026, P107 and P087 were unique isolates. The temperate phages from the two groups of phages (TP-40-3, TP-936-1) with isometric heads differ in tail length (Fig. 1).

\section{Restriction enzyme analysis}

To verify these groups based on morphological properties, a restriction enzyme analysis of the phage genomes was performed. The DNAs of phages of the P001 group and some of the P335 group (P335, P002 and P013) were highly refractory to the action of many restriction endonucleases. If any, a much lower than expected number of restriction sites was observed. Phages of the P001 group, propagated on Lactococcus lactis subsp. lactis H42, showed almost identical restriction profiles with several endonucleases (Fig. $3 a$ ) with the exception of phage P330 (Fig. 3a, lane 8), which was not cut by most of the restriction enzymes. Phage c6A, characterized in Australia by Powell \& Davidson (1985), could be distinguished from the other prolate-headed phages by its unique DNA restriction pattern (Fig. $3 a$, lane 11).

Two phages, P109 and P127, specific for Lactococcus lactis subsp. cremoris strains showed clearly different restriction patterns with several endonucleases, such as $\mathrm{HpalI}$ (Fig. $3 a$, lanes 3 and 4). The numerous members of the P008 group showed very similar restriction fragment profiles with several enzymes including EcoRI and TaqI (data not shown).

Within the P335 group and the temperate phage groups TP-936-1 and TP-40-3, phages revealed similar or even identical restriction enzyme patterns after digestion of the DNAs with various restriction endonucleases. Since the type phages P001 and P008 are the representatives of the most common virulent phages, restriction maps of these two phages were established. The restriction map of the isometric-headed phage P008 has already been published (Teuber \& Loof, 1987). The restriction map of the prolate-headed phage $P 001$ is presented in Fig. 2. By ligation of the phage DNA prior to digestion with restriction endonucleases and heating of the phage DNA for $15 \mathrm{~min}$ at $70^{\circ} \mathrm{C}$ after digestion (data not shown) it was proved that this molecule was linear with cohesive ends. A variety of restriction endonucleases did not cut the DNA of the phage P001 (Fig. 2). An analysis of its base composition by high performance liquid chromatography displayed no modified bases (S. Hertwig, A. Geis \& M. Teuber, unpublished data).

\section{DNA-DNA hybridization}

To determine the degree of homology of the phages within a group and among different groups, DNA-DNA hybridization with the DNAs of the type phages as probe was done. Phages within each group revealed strong DNA homology, as is shown in Fig. 3 for the prolateheaded phages of the $\mathrm{P} 001$ group. The $\mathrm{P} 001$ probe hybridized with all bands of the other phages, including phages P109, P127, and c6A that was grown on other host strains and showed different restriction profiles (Fig. 3). A similar result was obtained with the phages of the P008 group. All the phage DNAs from this group, even those with different restriction fragment profiles or from phages propagated on different host strains, hybridized strongly with the P008DNA probe.

No significant hybridization signals were found in cross-hybridization experiments using DNA probes prepared from the type phages P001, P008, P335, P107, P087, P034 and P026.

The grouping of the temperate phages according to morphological properties was also confirmed by DNA-DNA hybridization. The DNAs of the phages TP-901-1, TP-938-2, TP-3107, and TP-Wis98. 1 hybridized extremely well with the TP-936-1 DNA probe (Fig. 4), whereas little or no homology was found with the DNAs of TP-C10, TP-40-3 (Fig. 4, lanes 7 and 


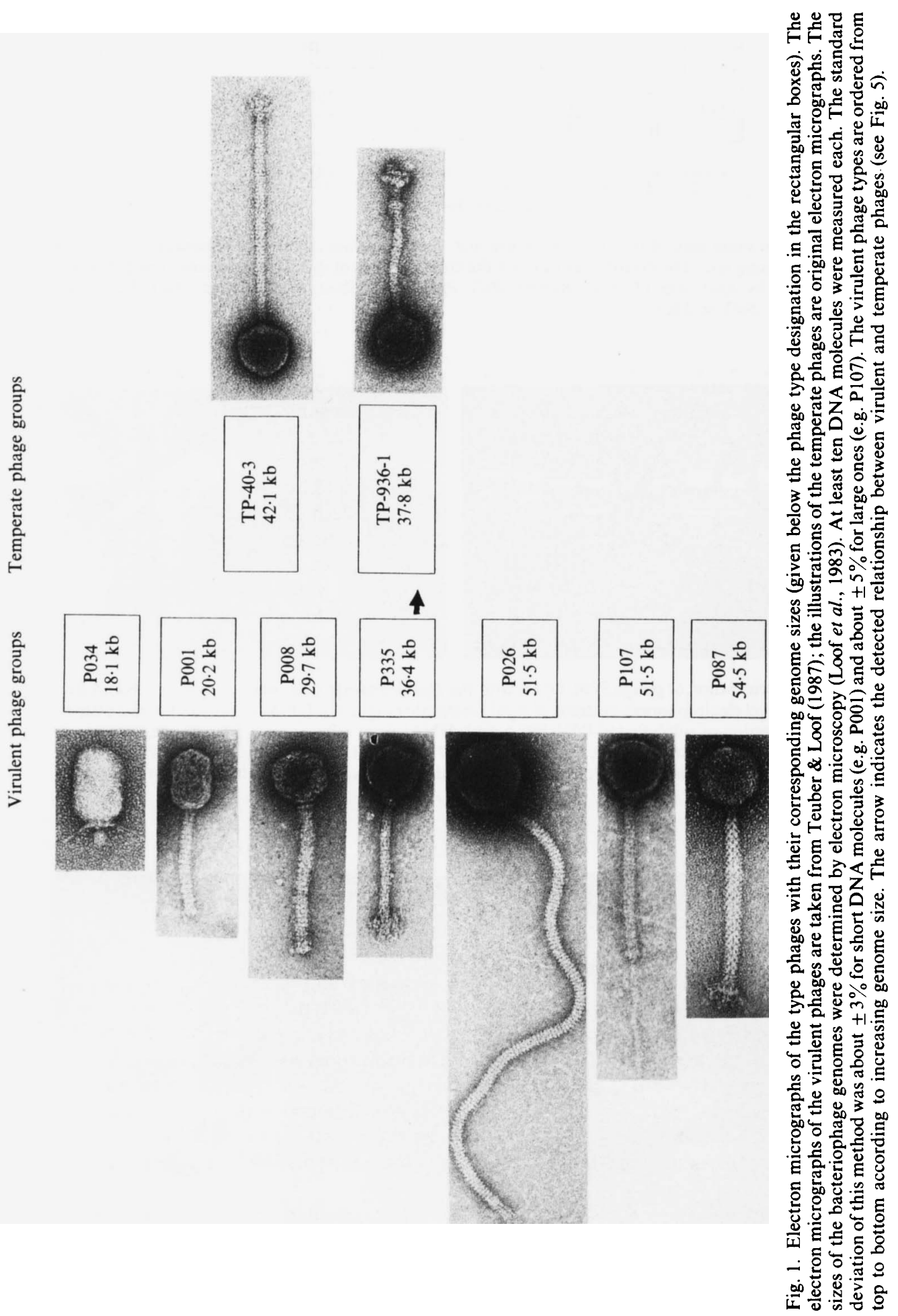




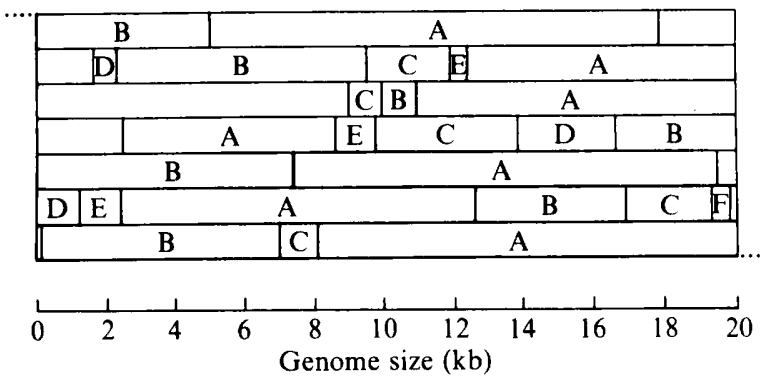

BstEII

EcoRI

HaelII

Hhal

HindIII

HpaII

MboI

Fig. 2. Restriction map of the P001 phage genome. Fragments are labelled alphabetically in order of their decreasing size. The dotted lines indicate the cohesive ends of the DNA molecule. The DNA was not cleaved by $A p a \mathrm{I}, A s p 718, A v a \mathrm{I}, B a m \mathrm{HI}, B c l \mathrm{I}, B g l \mathrm{I}, B g l \mathrm{II}, D p n \mathrm{I}, E c o \mathrm{RV}, K p n \mathrm{I}, N a e \mathrm{I}, P s t \mathrm{I}, P v u \mathrm{I}$, PvuII, SacI, SalI or XhoI.
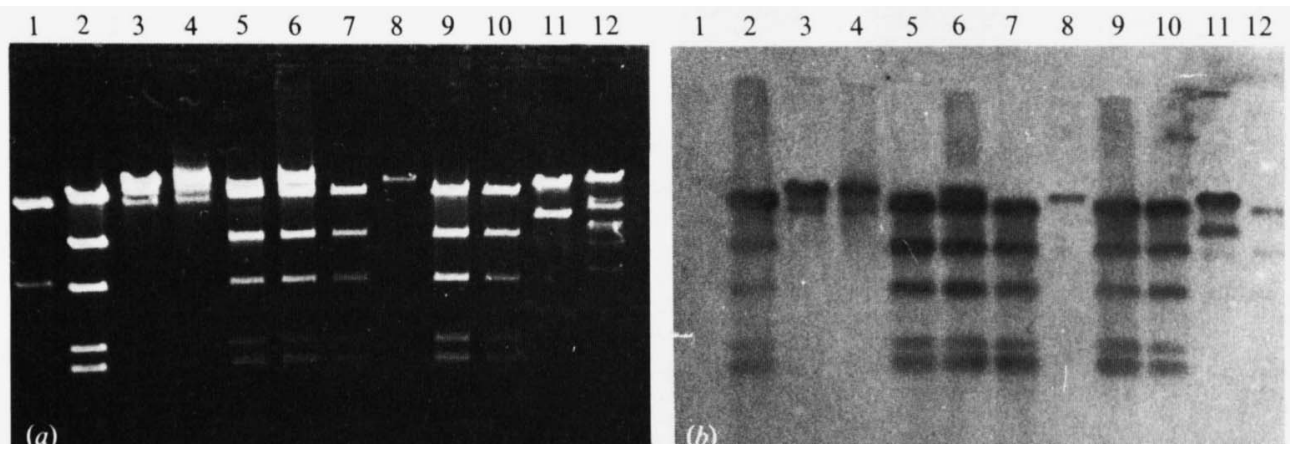

Fig. 3. Hybridization of phage P001 DNA with the HpaII fragments of other prolate-headed phages. (a) Agarose gel electrophoresis patterns of $\mathrm{HpaII}$ restriction digests of DNAs of prolate-headed phages. (b) Hybridization of sulphonated P001 DNA with DNAs from other prolate-headed phages. Lane 1, pBR322 (negative control); lane 2, P001; lane 3, P109; lane 4, P127; lane 5, P029; lane 6, P159; lane 7, P167; lane 8, P330; lane 9, P177; lane 10, P220; lane 11, c6A; lane 12, P107 (negative control).
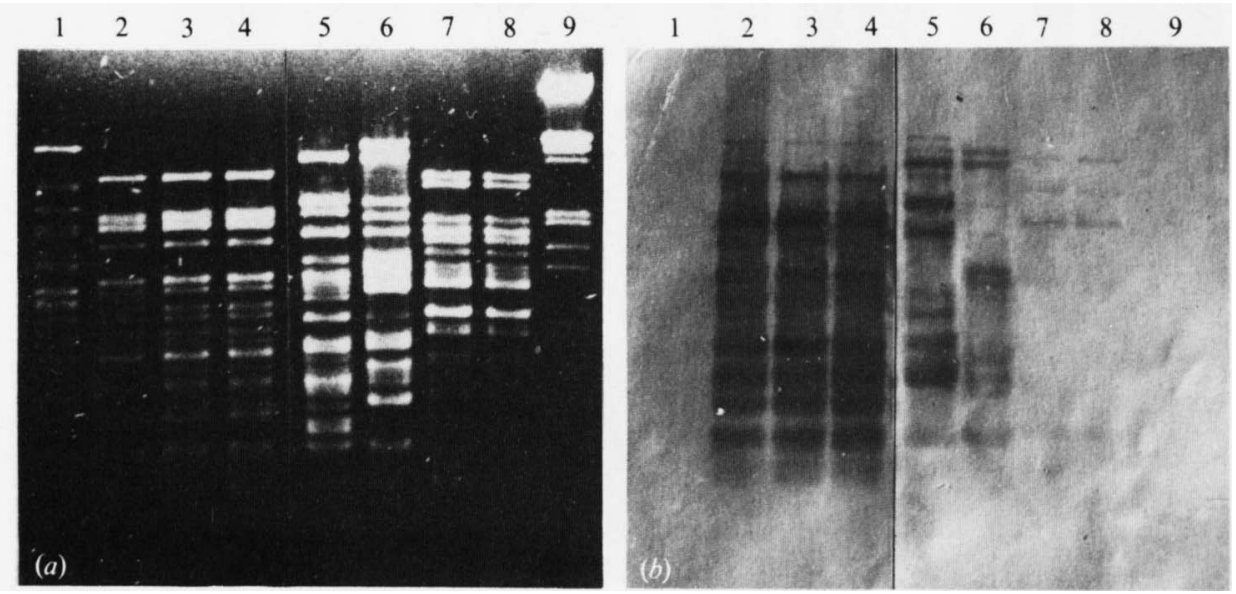

Fig. 4. Hybridization of the DNA of the temperate phage TP-936-1 with DraI fragments of the DNAs of other temperate phages. (a) Agarose gel electrophoresis patterns of DraI restriction digests of phage DNAs. (b) Hybridization of sulphonated TP-936-1 DNA with DraI fragments of the DNAs from other temperate phages. Lane 1, BK5-T; lane 2, TP-901-1; lane 3, TP-936-1; lane 4, TP-938-2; lane 5, TP-3107; lane 6, TP-Wis98.1; lane 7, TP-C10; lane 8, TP-40-3; lane 9, phage $\lambda$ (negative control). 

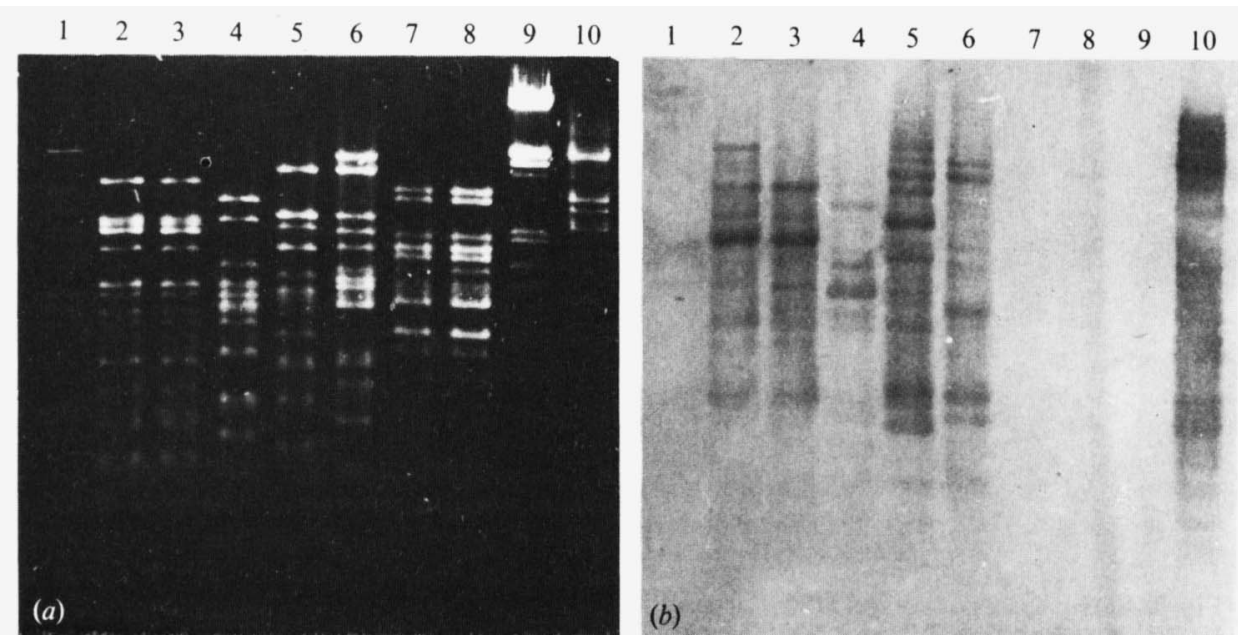

Fig. 5. Hybridization of the DNA of the virulent phage P335 with DraI DNA fragments of temperate phages. (a) Agarose gel electrophoresis patterns of DraI restriction digests of phage DNAs. (b) Hybridization of labelled P335 DNA with DNAs from temperate phages. Lane 1, BK5-T; lane 2, TP-936-1; lane 3, TP-938-2; lane 4, TP-Bu2-K5; lane 5, TP-3107; lane 6, TP-Wis98. 1; lane 7, TP-C10; lane $8, \mathrm{TP}-40-3$; lane 9 , phage $\lambda$ (negative control); lane 10, P335.

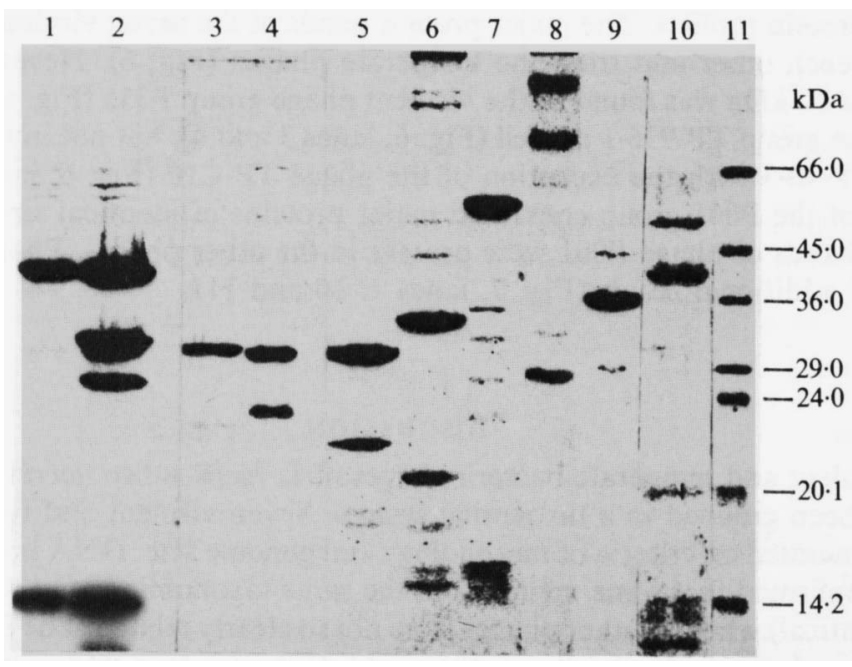

Fig. 6. SDS-polyacrylamide gel ( $12 \%)$ electrophoretic profiles of proteins of the virulent type phages and of some temperate phages. Lane 1, TP-40-3; lane 2, TP-C10; lane 3, TP-951-1; lane 4, TP-936-1; lane 5, P335; lane 6, P107; lane 7, P034; lane 8, P001; lane 9, P008; lane 10, P087; lane 11, SDS-7 (size standards).

8), and the temperate phage BK 5-T (Fig. 4, lane 1). This observation suggests that the temperate phages in Table 2 belong to at least two different groups and that the phage BK5-T is not related to one of these groups.

Temperate phage DNAs were also hybridized with labelled DNAs of the virulent type phages. The temperate phage group TP-936-1 (Fig. 5, lanes 2-6) displayed strong DNA homology of various degrees after hybridization with type phage P335, whereas the members of the temperate phage group TP-40-3 exhibited only very weak signals (Fig. 5, lanes 7 and 8), as did the temperate phage BK5-T (Fig. 5, lane 1).

The DNA homology between P335 and phages of group TP-936-1 indicates a close genetic relationship between these virulent and temperate phages. 


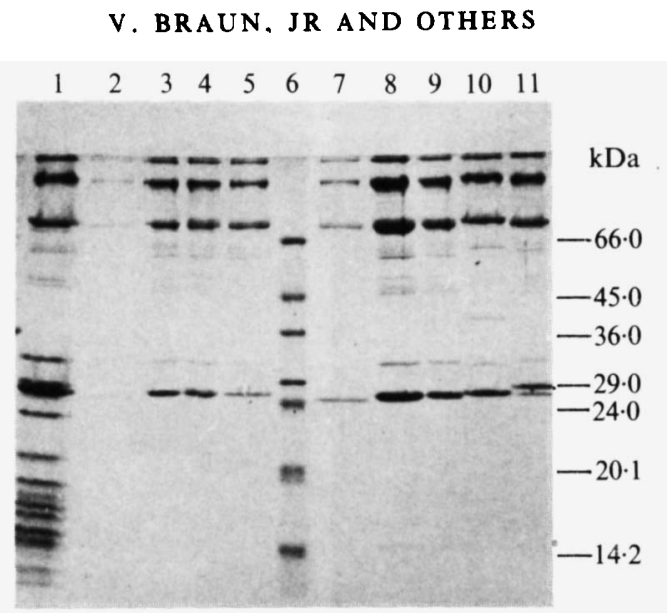

Fig. 7. SDS-polyacrylamide gel (12\%) electrophoretic profiles of proteins of prolate-headed phages. Lane 1, c6A; lane 2, P159; lane 3, P001; lane 4, P029; lane 5, P167; lane 6, SDS-7 (size standards); lane 7, P127; lane 8, P177; lane 9, P220; lane 10, P109; lane 11, P330.

\section{SDS-polyacrylamide gel electrophoresis}

Phage grouping according to the DNA-DNA hybridizations was confirmed by the analysis of the structural protein profiles. The major protein bands of the seven virulent type phages were different from each other and from the temperate phages (Fig. 6). Nevertheless, one major protein of about $30 \mathrm{kDa}$ was found in the virulent phage group P335 (Fig. 6, lane 5) and in the temperate phage group TP-936-1 as well (Fig. 6, lanes 3 and 4), but not in the other temperate phage group TP-40-3 with the exception of the phage TP-C10 (Fig. 6, lanes 1 and 2).

The phages of the P001 group contained major proteins of identical size. Also most of the minor protein bands of phage P001 were present in the other phages. Phages c6A, P109, and P330 exhibited additional bands (Fig. 7, lanes 1, 10 and 11).

\section{DISCUSSION}

Fifty-six virulent and temperate bacteriophages of L. lactis subsp. lactis and L. lactis subsp. cremoris have been grouped in a taxonomic system. Seven virulent and two temperate phage groups were generated on criteria of morphology and genome size. DNA homology and protein composition confirmed that some members of the same taxonomic group were very similar (in some cases identical) whereas other phages were not so clearly related. The P008 group seems to be widespread in cheese factories all over the world. Hybridization studies by other laboratories showed that this group is closely related to group III (France) of Relano et al. (1987), phage types $\mathrm{a}$ and $\mathrm{b}$ (New Zealand) described by Jarvis (1984a) and phages uc 1001 and uc 1002 (Ireland) of Coveney et al. (1987). Investigations by Heap \& Jarvis (1980) and Jarvis (1984a) demonstrated that prolate-headed phages were closely related. This is consistent with our experiments. Phage c6A (Australia), characterized in detail by Powell \& Davidson (1985), exhibited strong DNA homology and showed the same major protein bands as the other members of this group. We propose that all tailed prolate-headed phages published up to now belong to this one group, $\mathrm{P} 001 / \mathrm{c} 6 \mathrm{~A}$.

The relationship between virulent and temperate phages was also examined. We found evidence of a close relationship between the virulent phage group P335 and the temperate phage group TP-936-1. Cross-hybridizations between virulent and temperate phage DNAs were also found by Relano et al. (1987) and Lautier \& Novel (1987), but not by Jarvis (1984b). DNA homology, based on hybridization studies, was compatible with the protein compositions of the phages examined. Different phage groups (see Fig. 1) revealed different protein profiles (Fig. 6), 
whereas within the groups all members showed a similar or even identical protein composition (Fig. 7). One major protein of about $30 \mathrm{kDa}$ was found in the virulent P335 group as well as in the temperate phage group TP-936-1, but only in phage TP-C10 of the temperate TP-40-3 group.

Restriction enzyme analysis of phage DNA and host range patterns are not suitable for establishing a taxonomic system of bacteriophages of $L$. lactis. For example, phages of the P001 group, which exclusively infect $L$. lactis subsp. lactis or $L$. lactis subsp. cremoris strains and showed different restriction profiles, revealed strong DNA homology. Presumably, hostinduced modifications of the phage DNA change the restriction endonuclease patterns, as found by Daly \& Fitzgerald (1982). Prolate-headed phages propagated on the same host exhibited very similar or even identical restriction endonuclease patterns. This confirmed the strong DNA homology of these phages.

As previously reported, DNAs of some lactococcal bacteriophages are highly resistant to cleavage by many restriction endonucleases (Coveney et al., 1987; Jarvis \& Meyer, 1986; Powell $\&$ Davidson, 1986). This effect was also found in our experiments. However, no modified bases could be detected in a DNA base analysis of the prolate-headed type phage P001 by high performance liquid chromatography. Thus a paucity of cleavage sites of some lactococcal bacteriophage DNAs is the reason for the bias of these DNAs against cleavage by a number of restriction endonucleases. In accordance with Powell \& Davidson (1986) we suggest that this effect is an evolutionary response of these phages to restriction-modification systems of their bacterial hosts.

Some of the bacteriophage types defined in this publication [P001, P008, P270 (a phage of the P335 type), P369, P109] have already been deposited in the reference collection of Dr H.-W. Ackermann (Faculté de medicine, Departement de microbiologie, Cité Universitaire, Québec, Canada) and are therefore freely accessible for the scientific community.

This work was supported by a grant from the Commission of the European Communities within the Biotechnology Action Programme (BAP-0010-D). The technical assistance of B. Fahrenholz is gratefully acknowledged. We thank B. Henrich (University of Kaiserslautern) for improving our electrophoresis procedures and S. Paul for critical reading and comments.

\section{REFERENCES}

Baumgartner, A., Murphy, M., Daly, C. \& FitzGERALD, G. F. (1986). Conjugative co-transfer of lactose and bacteriophage resistance plasmids from Streptococcus cremoris UC653. FEMS Microbiology Letters 35, 233-237.

Coveney, J. A., Fitzgerald, G. F. \& Daly, C. (1987). Detailed characterization and comparison of four lactic streptococcal bacteriophages based on the morphology, restriction mapping, DNA homology, and structural protein analysis. Applied and Environmental Microbiology 53, 1439-1447.

DALY, C. \& FitzGERALD, G. F. (1982). Bacteriophage DNA restriction and the lactic streptococci. In Microbiology-1982, pp. 213-216. Edited by D. Schlessinger. Washington, DC: American Society for Microbiology.

DE Vos, W. M., Underwood, H. M. \& Davies, F. L. (1984). Plasmid encoded bacteriophage resistance in Streptococcus cremoris SK11. FEMS Microbiology Letters 23, 175-178.

Evenson, D. P. (1977). Electron microscopy of viral nucleic acids. Methods in Virology 6, 219-264.

HeaP, H. A. \& JARVIS, A. W. (1980). A comparison of prolate- and isometric-headed lactic streptococcal bacteriophages. New Zealand Journal of Dairy Science and Technology 15, 75-81.
JARVIS, A. W. (1984a). Differentiation of lactic streptococcal phages into phage species by DNADNA homology. Applied and Environmental Microbiology 47, 343-349.

JARVIS, A. W. (1984b). DNA-DNA homology between lactic streptococci and their temperate and lytic phages. Applied and Environmental Microbiology 47, 1031-1038.

JARVIS, A. W. \& MeYER, J. (1986). Electron microscopic heteroduplex study and restriction endonuclease cleavage analysis of the DNA genomes of three lactic streptococcal bacteriophages. Applied and Environmental Microbiology 51, 566-571.

Klaenhammer, T. R. (1987). Plasmid-directed mechanisms for bacteriophage defense in lactic streptococci. FEMS Microbiology Reviews 46, 313325.

LAEMMLI, U. K. (1970). Cleavage of structural proteins during the assembly of the head of bacteriophage T4. Nature, London 227, 680-685.

Laible, N. J., Rule, P. L., Harlander, S. K. \& MCKAY, L. L. (1987). Identification and cloning of plasmid deoxyribonucleic acid coding for abortive phage infection from Streptococcus lactis ssp. diacetylactis KR2. Journal of Dairy Science 70, 22112219. 
LAutier, M. \& Novel, G. (1987). DNA-DNA hybridizations among lactic streptococcal temperate and virulent phages belonging to distinct lytic groups. Journal of Industrial Microbiology 2, 151-158.

LembKe, J., KRUSCH, U., Lompe, A. \& Teuber, M. (1980). Isolation and ultrastructure of bacteriophages of group N (lactic) streptococci. Zentralblatt für Bakteriologie (Abteilung I, Originale C) 1, 7991.

LOOF, M., LembKe, J. \& Teuber, M. (1983). Characterization of the genome of the Streptococcus lactis subsp. diacetylactis bacteriophage P008 wide-spread in German cheese factories. Systematic and Applied Microbiology 4, 413-423.

Maniatis, T., Fritsch, E. F. \& SAmbroOK, J. (1982). Molecular Cloning: a Laboratory Manual. Cold Spring Harbor, NY: Cold Spring Harbor Laboratory.

McKaY, L. L. \& Baldwin, K. A. (1984). Conjugative 40-megadalton plasmid in Streptococcus lactis subsp. diacetylactis DRC3 is associated with resistance to nisin and bacteriophage. Applied and Environmental Microbiology 47, 68-74.

Neve, H., Geis, A. \& Teuber, M. (1987). Conjugation, a common plasmid transfer mechanism in lactic acid streptococci of dairy starter cultures. Systematic and Applied Microbiology 9, 151-157.

Powell, J. B. \& Davidson, B. E. (1985). Characterization of streptococcal bacteriophage c6A. Journal of General Virology 66, 2737-2741.

Powell, J. B. \& DAvidson, B. E. (1986). Resistance to in vitro restriction of DNA from lactic streptococcal bacteriophage c6A. Applied and Environmental Microbiology 51, 1358-1360.

Relano, P., Mata, M., Bonneau, M. \& RitzenTHALER, P. (1987). Molecular characterization and comparison of 38 virulent and temperate bacteriophages of Streptococcus lactis. Journal of General Microbiology 133, 3053-3063.
Sanders, M. E. \& Klaenhammer, T. R. (1983). Characterization of phage-insensitive mutants from a phage-sensitive strain Streptococcus lactis: evidence for a plasmid determinant that prevents phage adsorption. Applied and Environmental Microbiology 46, 1125-1133.

Simon, D., Rouault, A. \& Chopin, M.-C. (1985). Protoplast transformation of group $\mathrm{N}$ streptococci with cryptic plasmids. FEMS Microbiology Letters 26, 239-241.

SOUTHERN, E. M. (1975). Detection of specific sequences among DNA fragments separated by gel electrophoresis. Journal of Molecular Biology 98, 503-517.

Terzaghi, B. E. \& Sandine, W. E. (1975). Improved medium for lactic streptococci and their bacteriophages. Applied Microbiology 29, 807-813.

TEUBER, M. \& LeMBKE, J. (1983). The bacteriophages of lactic acid bacteria with emphasis on genetic aspects of group $\mathrm{N}$ lactic streptococci. Antonie van Leeuwenhoek 49, 283-295.

TEUBER, M. \& LOOF, M. (1987). Genetic characterization of lactic streptococcal bacteriophages. In Streptococcal Genetics, pp. 250-258. Edited by J. J. Ferretti \& R. E. Curtiss III. Washington, DC: American Society for Microbiology.

Wetzel, A., Neve, H., Geis, A. \& Teuber, M. (1986). Transfer of plasmid-mediated phage resistance in lactic acid streptococci. Chemie Mikrobiologie Technologie der Lebensmittel 10, 86-89.

WhITEHEAD, H. R. \& CoX, G. A. (1935). The occurrence of bacteriophages in starter cultures of lactic streptococci. New Zealand Journal of Science and Technology 16, 319-320.

Yamamoto, K. R., Alberts, B. M., Benzinger, R., LAWHORNE, L. \& TREIBER, G. (1970). Rapid bacteriophage sedimentation in the presence of polyethylene glycol and its application to large scale virus purification. Virology 40, 734-744. 